\title{
Circadian clock genes and the transcriptional architecture of the clock mechanism
}

\author{
Kimberly H Cox ${ }^{1}$ and Joseph S Takahashi ${ }^{1,2}$ \\ 'Department of Neuroscience, Peter O'Donnell Jr. Brain Institute, The University of Texas Southwestern Medical Center, Dallas, Texas, USA \\ 2Howard Hughes Medical Institute, University of Texas Southwestern Medical Center, Dallas, Texas, USA
}

Correspondence should be addressed to J S Takahashi: Joseph.Takahashi@UTSouthwestern.edu

\begin{abstract}
The mammalian circadian clock has evolved as an adaptation to the 24-h light/ darkness cycle on earth. Maintaining cellular activities in synchrony with the activities of the organism (such as eating and sleeping) helps different tissue and organ systems coordinate and optimize their performance. The full extent of the mechanisms by which cells maintain the clock are still under investigation, but involve a core set of clock genes that regulate large networks of gene transcription both by direct transcriptional activation/repression as well as the recruitment of proteins that modify chromatin states more broadly.
\end{abstract}

\section{Key Words \\ - mammalian \\ - circadian clock \\ - transcription \\ - clock genes}

Journal of Molecular Endocrinology (2019) 63, R93-R102

\section{Introduction}

The 24-h rotation of the Earth has been a major evolutionary force on the development of intrinsic circadian clocks in most species (Pittendrigh 1993). In plants that require light for energy production, it is obvious why there is a metabolic link to the day/night cycle (Greenham \& McClung 2015); however, animals have also adapted behavioral changes corresponding with light and temperature cycles to respond to and anticipate energetic demands (Bass \& Takahashi 2010). In addition to rhythmicity in sleep/activity cycles, in mammals, there are also many other examples of 24-h physiological rhythms, including body temperature fluctuations (Buhr et al. 2010), circulating hormone levels (Lightman 2016), and metabolism (Green et al. 2008).

An important (and defining) aspect of circadian rhythms is that they persist in the absence of external cues (Pittendrigh \& Daan 1976); yet, external cues are important for synchronizing or entraining rhythms. It was originally thought that most circadian rhythms were entrained by light (Pittendrigh 1960); however, light is merely one of the many cues that can entrain the circadian clock. Moreover, while research on the mammalian circadian clock was long focused on the suprachiasmatic nucleus of the hypothalamus (SCN) as the central pacemaker (Welsh et al. 2010, Hastings et al. 2018), we now know that the circadian clock itself is actually an intrinsic property of cells in many different tissues (Yoo et al. 2004), with the SCN serving to synchronize 'peripheral' clocks (Albrecht 2012, Mohawk et al. 2012). The specific machinery underlying circadian clocks differ from organism to organism, but at the cellular level they depend on the transcription of sets of core clock genes, underscoring the evolutionary conservation of the core clock mechanism across species (Dunlap 1999, Bell-Pedersen et al. 2005).

This review will describe what the field has learned about mammalian clock genes and the regulation of circadian gene transcription across tissues, with a focus on how these circadian genes influence metabolic pathways. While it is by no means exhaustive, it provides an overview of aspects of the circadian clock that the 
Takahashi lab continues investigating and highlights unresolved questions that remain of great interest to the circadian field.

\section{Cast of characters: the mammalian circadian clock}

The first clock gene, period, was discovered through investigations of Drosophila mutants with abnormal behavioral cycles (Konopka \& Benzer 1971, Smith \& Konopka 1981, Reddy et al. 1984). These important studies laid the foundation for understanding the molecular basis of the clock, as the per gene was found to exhibit a circadian rhythm and the PER protein, itself, was found to regulate per gene expression (Hardin et al. 1990). Extending the studies in Drosophila, the first mammalian core clock gene, Clock, was discovered in a forward genetics screen for mice with abnormal circadian behavioral patterns (Vitaterna et al. 1994, King et al. 1997). The CLOCK protein in mice has features in common with Drosophila PER, including a PAS domain (for Per, ARNT, and Sim). However, CLOCK and its binding partner, BMAL1 (Gekakis et al. 1998), also have bHLH domains that allow them to bind DNA directly to regulatory elements (E-boxes) on rhythmic genes to influence their transcription.

The major targets of CLOCK/BMAL1 include other core clock genes that encode the mammalian Period ortholog (Per1, Per2, and Per3) (Shearman et al. 1997) and CRYPTOCHROME (Cry1 and Cry2) (Kume et al. 1999) repressor proteins. These negative regulators heterodimerize and then translocate into the nucleus where they repress their own gene transcription by interacting directly with CLOCK/BMAL1 (Michael et al. 2017, Rosensweig et al. 2018). In addition to this direct transcriptional feedback, the mRNA expression of Per $1 / 2 / 3$ and $\operatorname{Cry} 1 / 2$ is also regulated by various mechanisms (Kojima et al. 2011, Lim \& Allada 2013). The degradation of PER and CRY proteins is also regulated by the serine/threonine kinases, casein kinase $1 \delta(\mathrm{CK} 1 \delta)$ and CK1є (Gallego \& Virshup 2007, Narasimamurthy et al. 2018), the F-box proteins, FBXL3 and FBXL21 (Hirano et al. 2013, Yoo et al. 2013), and other proteins (Reischl et al. 2007). Once negative transcriptional feedback and post-transcriptional and post-translational regulation is sufficient to decrease PER/CRY protein levels in the nucleus, repression is relieved and CLOCK/BMAL1 starts a new cycle of Per/Cry gene transcription (Takahashi 2017).

Since the initial discovery of these core mammalian clock genes, several additional genes and feedback loops have been uncovered, increasing the complexity of the mammalian circadian clock gene network (Fig. 1). In the second major transcriptional loop, CLOCK/BMAL1 activate transcription of genes for the nuclear receptors REV-ERB $\alpha$ and REV-ERB $\beta$ (Preitner et al. 2002). These proteins compete with the retinoic acid-related orphan receptors ROR $\alpha, \mathrm{ROR} \beta$, and ROR $\gamma$ for binding sites (RORbinding elements) on the Bmal1 gene, providing both positive (ROR) and negative (REV-ERB) regulation of transcription (Sato et al. 2004), and, as will be discussed later, they make an important link between the circadian clock and metabolism (Zhang et al. 2015). A third feedback loop involves the D-box binding protein (DBP) and the nuclear factor, interleukin-3-regulated protein (NFIL3, also known as E4BP4) which are regulated by CLOCK/BMAL1 (Ripperger \& Schibler 2006) and CRY1 (Stratmann et al. 2010) and bind to D-box elements on circadian promoters, including Rora and Rorb (Ueda et al. 2005). Together, these feedback loops that make up the 'molecular clock' are governed by transcriptional (Takahashi 2017), post-transcriptional (Kojima \& Green 2015), and post-translational (Gallego \& Virshup 2007) regulatory mechanisms that are sufficient to maintain circadian rhythms; however, external cues are still important for synchronizing rhythms of cells within and across tissues (Golombek \& Rosenstein 2010).

\section{Circadian rhythms throughout the body}

Early studies of mammalian circadian rhythms suggested that the brain responds to light cues to regulate sleep/wake cycles and daily behavioral and neuroendocrine rhythms. The discovery of axons projecting from the retina to the suprachiasmatic nucleus of the hypothalamus (SCN) (Moore \& Lenn 1972) gave insights into the central pathway mediating these effects, and subsequent lesioning and transplantation studies established the SCN as a master regulator of circadian rhythms (Moore \& Eichler 1972, Stephan \& Zucker 1972, Ralph et al. 1990). It was not until several years later that a specialized population of retinal ganglion cells (intrinsically photosensitive 'ipRGCs') containing the photopigment, melanopsin, were discovered (Provencio et al. 2000, Berson et al. 2002, Hattar et al. 2002). The light information transmitted by ipRGCs via the retinohypothalamic tract is sufficient to set the phase of the SCN (Guler et al. 2008), which responds by generating circadian patterns of action potentials (Hastings et al. 2018).

The SCN consists of a heterogeneous cluster of approximately 10,000 neurons in the ventral hypothalamus (Welsh et al. 2010). There are two main 


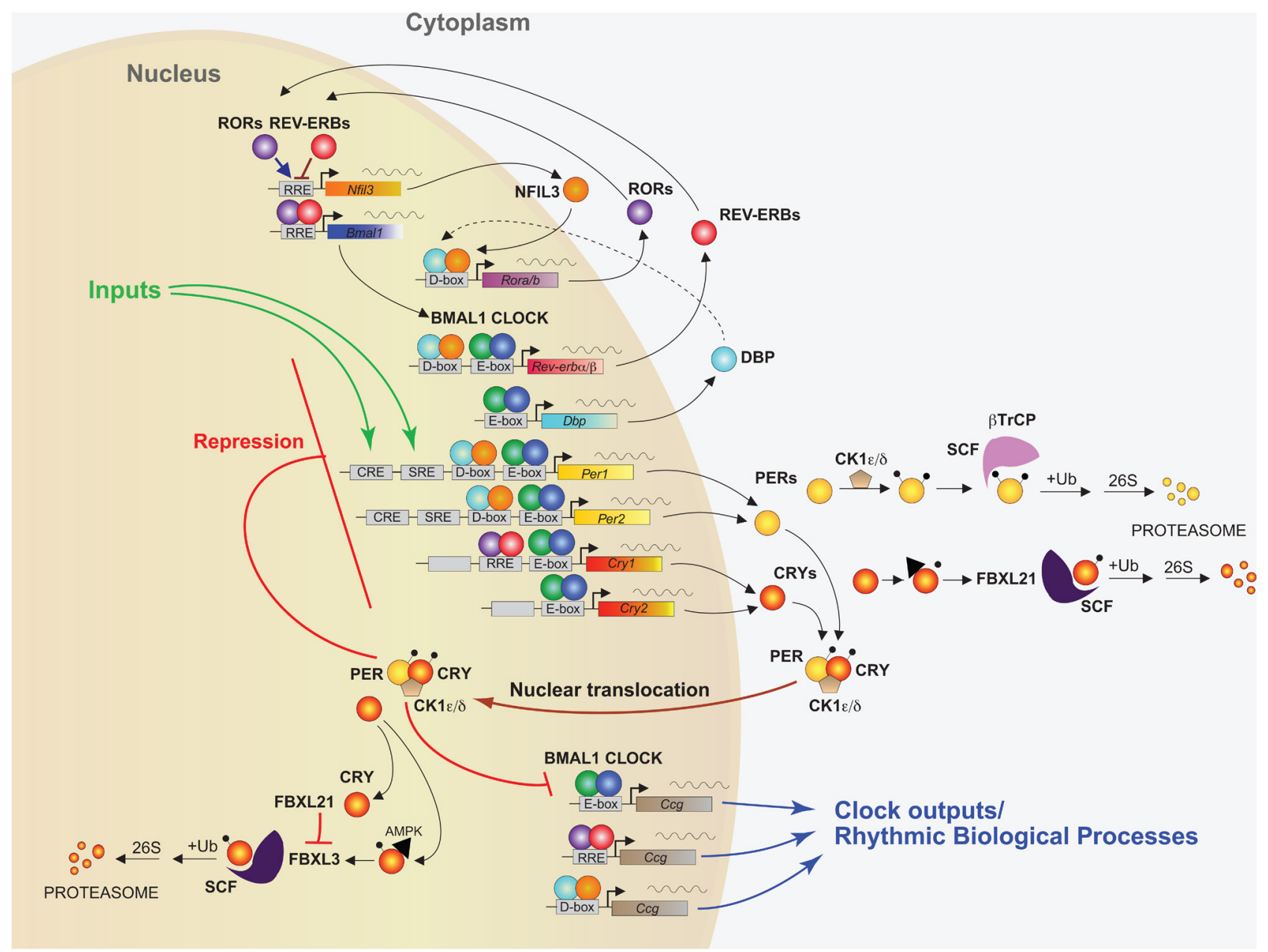

\section{Figure 1}

Core components of the mammalian circadian clock. In the core feedback loop, the transcription factors BMAL1 (green circles) and CLOCK (blue circles) bind to E-box domains on gene promoters, including the genes for Per1 and Per2 (yellow) and Cry1 and Cry2 (red/yellow). PERs (yellow circles) and CRYs

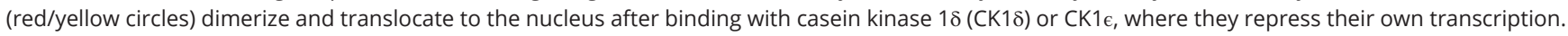
The stability of PER and CRY is regulated both in the cytoplasm and within the nucleus by several proteins, including FBXL21 and FBXL3. In a second feedback loop, CLOCK and BMAL1 also regulate the transcription of genes for the nuclear receptors REV-ERB $\alpha$ and REV-ERB $\beta$ (red circles), which compete with the retinoic acid-related orphan receptors, ROR $\alpha$, ROR $\beta$, and ROR $\gamma$ (purple circles) for binding to RRE elements on the BMAL1 gene promoter, providing both positive (ROR) and negative (REV-ERB) regulation of BMAL1 transcription. A third feedback loop is mediated by CLOCK/BMAL1-mediated transcription of the gene Dbp (light blue) and the ROR/REV-ERB-mediated transcription of Nfil3 (orange). DBP (light blue circles) and NFIL3 (orange circles) dimerize and bind to D-box elements on the promoters of many of the core clock genes, providing additional layers of regulation. In addition, CLOCK/ BMAL1, ROR/REV-ERB, and DBP/NFIL3 regulate the transcription of many other clock output genes (Figure modified from; Takahashi 2017).

subdivisions of SCN neurons, defined based on their expression of the neuropeptides arginine vasopressin (AVP) and vasoactive intestinal peptide (VIP). However, almost all SCN neurons express the inhibitory neurotransmitter GABA (Okamura et al. 1989), and there are several other neuropeptides that are expressed across the SCN, increasing the complexity of these subregions (Abrahamson \& Moore 2001, Hastings et al. 2018). The VIP-expressing neurons in the ventrolateral 'core' of the SCN receive synaptic inputs from ipRGCs, and the response of these neurons is thought to be important for maintaining synchrony within the SCN. However, there is recent evidence to suggest that astrocytes within the SCN are also important for maintaining synchrony (Brancaccio et al. 2017, 2019), so the story is likely not so simple.

The response of SCN neurons to incoming light signals is well characterized and involves the activation of NMDA receptors on SCN neurons, calcium activation of CAMKII, and the activation of gene transcription (Golombek \& Rosenstein 2010). Of the core clock components, the Per1 and Per2 genes are particularly responsive to photic entrainment and have been used as a molecular marker for circadian oscillations (Yamazaki et al. 2000, Yoo et al. 2004). In addition, the expression of many other genes in 
the SCN, including immediate early genes, are induced by light (Porterfield et al. 2007).

Aside from the SCN, the circadian clock is also intrinsic to cells in many other tissues (Mohawk et al. 2012). This has been shown in isolated cells (Balsalobre et al. 1998, Yagita et al. 2001, Welsh et al. 2004), in rodent models generated to visualize PER gene expression rhythms from various tissues (Yamazaki et al. 2000, Yoo et al. 2004) and in studies of rhythmic gene expression across different tissues (Panda et al. 2002, Storch et al. 2002, Zhang et al. 2014). As will be discussed in more detail later, these other tissues respond to the signals coordinated by the SCN, but can also entrain to signals other than light (Damiola et al. 2000, Stokkan et al. 2001, Vollmers et al. 2009). Therefore, although the SCN serves to synchronize these 'peripheral' clocks, SCN inputs are not required for maintaining circadian timing in these other tissues (Albrecht 2012, Mohawk et al. 2012, Hastings et al. 2018).

\section{Mechanisms of circadian transcriptional regulation}

The main output of the core circadian clock includes genes regulated by CLOCK/BMAL1 (Takahashi 2017), REVERBs/RORs (Ueda et al. 2002), and DBP (Ripperger \& Schibler 2006), but there is also evidence that PER1 and CRY1/2 regulate expression of genes outside of the core regulatory feedback loop (Lamia et al. 2011). Within the past decade, there has been great interest in understanding how circadian transcription factors drive the rhythmic expression of a variety of genes across different tissues (Koike et al. 2012, Menet et al. 2012). CLOCK and BMAL1 form a much larger complex with histone modifying enzymes (Katada \& Sassone-Corsi 2010) and transcriptional coactivators such as Sirtuin 1 and CBP/p300 (Nakahata et al. 2008, Lee et al. 2010) to open chromatin and promote gene expression (Menet et al. 2014), along with the rhythmic recruitment of RNA polymerase (Takahashi 2017).

Taking a single gene $(D b p)$ as an example, one can observe the core clock transcription factors binding to the gene promoter at varying times throughout the day, as well as cyclic changes in chromatin state (Ripperger \& Schibler 2006, Koike et al. 2012). When one starts to look genome-wide, it becomes apparent that there are large-scale changes in transcription and chromosomal organization mediated by the circadian clock (Fig. 2) (Koike et al. 2012, Le Martelot et al. 2012, Menet et al. 2012, Vollmers et al. 2012, Takahashi 2017). While some of these chromosomal changes are associated with promoters or enhancers, recent studies have shown that long-range chromatin interactions also show rhythmic changes (Xu et al. 2016, Kim et al. 2018, Mermet et al. 2018, Yeung \& Naef 2018, Pacheco-Bernal et al. 2019). The field is still just beginning to understand what factors mediate these large changes in topology, but this is an exciting area in circadian research, particularly since chromatin interactions may underlie tissue-specific regulation of gene expression (Abruzzi et al. 2011, Yeung et al. 2018). Moreover, although most of the genome-wide studies have been performed using liver tissues, the latest evidence suggests that BMAL1 binding is highly variable across tissues and depends upon other tissue-specific transcription factors (Perelis et al. 2015, Beytebiere et al. 2019). Since some of the core clock transcription factors are also differentially expressed in specific tissues, it is likely that there are even more complex interactions of the circadian clock with tissue-specific factors.

\section{Circadian control of metabolism}

As major outputs of the circadian clock, CLOCK/BMAL1 regulate the transcription of thousands of genes (Koike et al. 2012, Menet et al. 2014, Beytebiere et al. 2019). In the liver there are about 3000 genes that display circadian

\section{Circadian Transcriptional Regulation in the Mouse Liver}

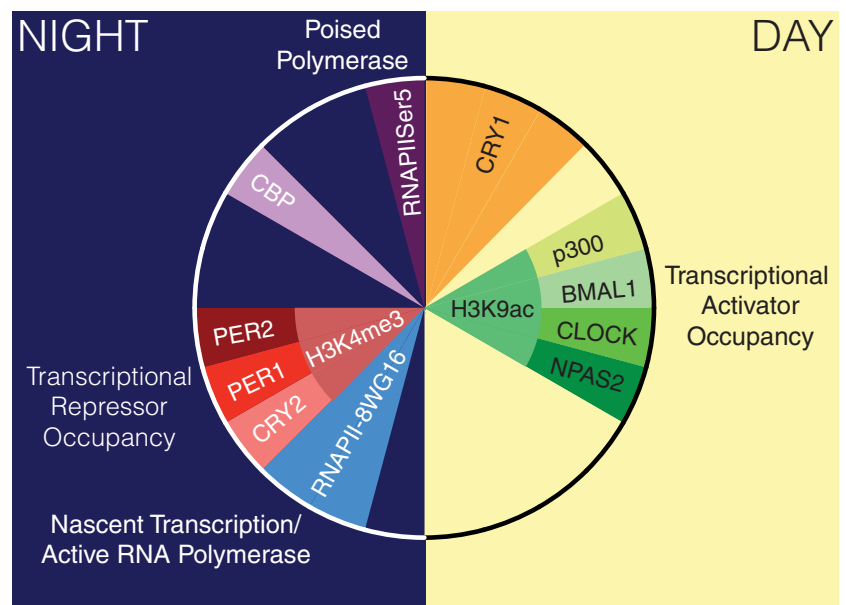

\section{Figure 2}

24-h depiction of genome-wide circadian transcriptional regulation in the mouse liver. Peak occupancy of transcriptional activators at gene promoters occurs in the middle of the day and corresponds with a peak in H3K9acetylation. Peak transcription occurs shortly after nightfall, as indicated by activated RNA polymerase binding. Transcriptional repressor occupancy peaks shortly thereafter, and corresponds with a peak in Hk34 tri-methylation. Additional transcription factors and co-factors, such as CRY1 and CBP appear to occupy promoters at different times, and poised RNA polymerase occupancy peaks just at the end of the 24-h cycle (Based on data from; Koike et al. 2012 and figure from; Takahashi 2017). 


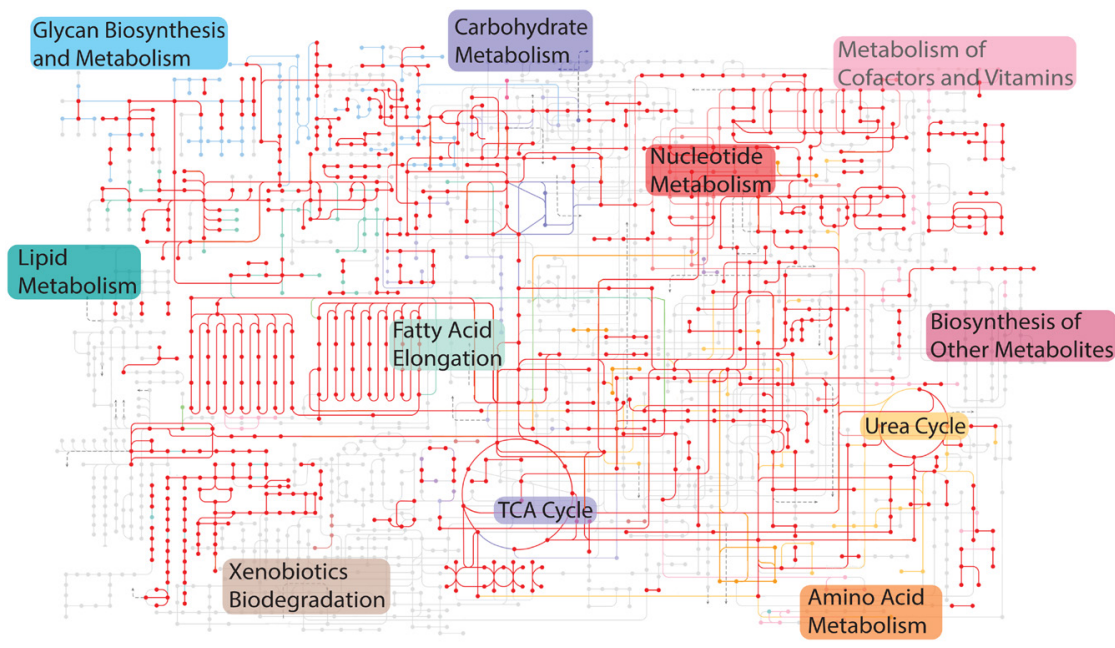

Figure 3

BMAL1 regulation of metabolism. Overlay of BMAL1 target genes (indicated in red) on diverse metabolic pathways in the liver. BMAL1 occupancy data are from a previously published ChIP-seq dataset (Koike et al. 2012). The original metabolic pathway is from a KEGG analysis (used with permission) and has been simplified to show major nodes (Kanehisa \& Goto 2000, 2017). In KEGG, nodes indicate enzymes and lines indicate connections in metabolic pathways, with colors indicating pathways serving similar functions. The red dots and lines indicate BMAL1 interactions with genes involved in these pathways. rhythms in BMAL1 occupancy (Koike et al. 2012), and many of these genes are involved in regulating cellular metabolic pathways (Fig. 3). CLOCK/BMAL1 regulation of whole-body metabolism has been noted previously, both in genomics studies and also in Clock and Bmal1 mutant mice, which display obesity and features of metabolic syndrome, such as altered glucose homeostasis, as well as disrupted skeletal muscle metabolism (Turek et al. 2005, Marcheva et al. 2010, Perelis et al. 2015, Harfmann et al. 2016). In addition, the transcriptional targets of REV-ERBs also connect the core clock machinery with metabolic pathways by regulating glucose and fatty acid metabolism (Cho et al. 2012, Delezie et al. 2012, Zhang et al. 2015), and Cry1 expression is associated with a reduction in gluconeogenesis in the liver (Zhang et al. 2010). Posttranscriptional regulation of core clock components also influences circadian gene expression in the liver (Wang et al. 2018), and many recent studies have shown that large-scale changes in the circadian epigenome (Sun et al. 2011, Vollmers et al. 2012, Masri et al. 2013) accompany the changes in metabolic gene expression. There are also several examples of genes involved in metabolic pathways that directly impact the expression of core clock genes (Asher et al. 2008, Lamia et al. 2009, Eckel-Mahan et al. 2013, Furlan et al. 2019). Thus, the core circadian clock is intimately linked to metabolism at the molecular level (Bass \& Lazar 2016, Challet 2019).

However, links between the circadian clock and metabolism were first made in studies showing that the liver circadian clock could be entrained by feeding time independently from the central SCN clock (Damiola et al. 2000, Stokkan et al. 2001). Since that time, many different feeding paradigms have shown that circadian gene expression in peripheral tissues is altered when the type or timing of food intake is manipulated (Vollmers et al. 2009, Eckel-Mahan et al. 2013, Mukherji et al. 2015). The circadian clock within several peripheral tissues, including the liver, skeletal muscle, and pancreas, is sensitive to hormonal signals and glucose levels (Saini et al. 2013, Dyar et al. 2014, Perelis et al. 2015, Schibler et al. 2015, Harfmann et al. 2016, Ikeda et al. 2018, Crosby et al. 2019), providing mechanisms through which food entrainment could occur. Interestingly, recent evidence suggests that, at least in the liver, the cell-autonomous circadian clock also depends on light synchronization and that food intake per se has large effects on transcription independent of effects on circadian gene expression (Atger et al. 2015, Greenwell et al. 2019, Koronowski et al. 2019). Thus, the simplistic view of liver clock being entrained by food, while the SCN is entrained by light, does not give sufficient credit to the complexity of the peripheral clock (Albrecht 2012, Izumo et al. 2014).

What is clear, is that synchronization of central and peripheral clocks is important for overall health (Di Francesco et al. 2018, Dyar et al. 2018, Challet 2019), and one of the most salient factors for this circadian synchronization appears to be the timing of food intake (Barclay et al. 2012, Hatori et al. 2012, Chaix et al. 2019). Notably, while caloric restriction paradigms have been successful in improving overall health and extending lifespan (Weindruch et al. 1986), these paradigms inadvertently impose temporal restriction of food intake. This was shown recently by my laboratory in experiments using automatic feeder cages that allowed us to regulate food intake as well as record activity of hundreds of mice simultaneously. We found that, under caloric restriction, mice consolidate their feeding to a 2 -h time interval, thus, self-imposing a time-restricted feeding pattern 
(Acosta-Rodriguez et al. 2017). These findings strongly suggest that for optimal metabolic performance, the timing of food intake must align with other circadian rhythms (i.e. activity, hormone secretion, temperature fluctuations).

\section{Conclusions/perspectives}

While this review has only been able to touch on some of the highlights of work on circadian transcriptional regulation, the data show that the circadian regulation of gene expression is pervasive and extends far beyond CLOCK/BMAL1 occupancy on gene promoters, including RNA polymerase recruitment, the modulation of chromatin states, chromatin architecture, and nuclear localization. In addition, clock genes and the pathways they regulate are undoubtedly embedded in metabolic pathways as shown both by the effects of the timing of food intake as well as the intrinsic links to metabolic gene networks. Thus, multi-faceted levels of regulation of circadian gene transcription allow the organism to anticipate metabolic demands and optimize energy utilization by consolidating gene expression to certain times of day. Interestingly, emerging results from my laboratory suggest that the circadian regulation of the timing of metabolic events may be critical for maintaining health and extending lifespan. Using circadian gene transcription as a window into the overall synchrony of an organism, we hope to continue to learn about additional factors involved in the circadian regulation of transcription, which will no doubt give us perspective on the underlying basis for many human diseases.

\section{Declaration of interest}

The authors declare that there is no conflict of interest that could be perceived as prejudicing the impartiality of the research reported.

\section{Funding}

J S T is supported by the NIH (R01 NS106657) and is an Investigator in the Howard Hughes Medical Institute.

\section{References}

Abrahamson EE \& Moore RY 2001 Suprachiasmatic nucleus in the mouse: retinal innervation, intrinsic organization and efferent projections. Brain Research 916 172-191. (https://doi.org/10.1016/ s0006-8993(01)02890-6)

Abruzzi KC, Rodriguez J, Menet JS, Desrochers J, Zadina A, Luo W, Tkachev S \& Rosbash M 2011 Drosophila CLOCK target gene characterization: implications for circadian tissue-specific gene expression. Genes \& Development 25 2374-2386. (https://doi org/10.1101/gad.178079.111)

Acosta-Rodriguez VA, De Groot MHM, Rijo-Ferreira F, Green CB \& Takahashi JS 2017 Mice under caloric restriction self-impose a temporal restriction of food intake as revealed by an automated feeder system. Cell Metabolism 26 267-277.e2. (https://doi. org/10.1016/j.cmet.2017.06.007)

Albrecht U 2012 Timing to perfection: the biology of central and peripheral circadian clocks. Neuron 74 246-260. (https://doi. org/10.1016/j.neuron.2012.04.006)

Asher G, Gatfield D, Stratmann M, Reinke H, Dibner C, Kreppel F, Mostoslavsky R, Alt FW \& Schibler U 2008 SIRT1 regulates circadian clock gene expression through PER2 deacetylation. Cell 134 317328. (https://doi.org/10.1016/j.cell.2008.06.050)

Atger F, Gobet C, Marquis J, Martin E, Wang J, Weger B, Lefebvre G, Descombes P, Naef F \& Gachon F 2015 Circadian and feeding rhythms differentially affect rhythmic mRNA transcription and translation in mouse liver. Proceedings of the National Academy of Sciences of the United States of America 112 E6579-E6588. (https://doi. org/10.1073/pnas.1515308112)

Balsalobre A, Damiola F \& Schibler U 1998 A serum shock induces circadian gene expression in mammalian tissue culture cells. Cell 93 929-937. (https://doi.org/10.1016/s0092-8674(00)81199-x)

Barclay JL, Husse J, Bode B, Naujokat N, Meyer-Kovac J, Schmid SM, Lehnert H \& Oster H 2012 Circadian desynchrony promotes metabolic disruption in a mouse model of shiftwork. PLOS ONE 7 e37150. (https://doi.org/10.1371/journal.pone.0037150)

Bass J \& Lazar MA 2016 Circadian time signatures of fitness and disease. Science 354 994-999. (https://doi.org/10.1126/science.aah4965)

Bass J \& Takahashi JS 2010 Circadian integration of metabolism and energetics. Science 330 1349-1354. (https://doi.org/10.1126/ science.1195027)

Bell-Pedersen D, Cassone VM, Earnest DJ, Golden SS, Hardin PE, Thomas TL \& Zoran MJ 2005 Circadian rhythms from multiple oscillators: lessons from diverse organisms. Nature Reviews. Genetics 6 544-556. (https://doi.org/10.1038/nrg1633)

Berson DM, Dunn FA \& Takao M 2002 Phototransduction by retinal ganglion cells that set the circadian clock. Science 295 1070-1073. (https://doi.org/10.1126/science.1067262)

Beytebiere JR, Trott AJ, Greenwell BJ, Osborne CA, Vitet H, Spence J, Yoo SH, Chen Z, Takahashi JS, Ghaffari N, et al. 2019 Tissue-specific BMAL1 cistromes reveal that rhythmic transcription is associated with rhythmic enhancer-enhancer interactions. Genes \& Development 33 294-309. (https://doi.org/10.1101/gad.322198.118)

Brancaccio M, Edwards MD, Patton AP, Smyllie NJ, Chesham JE, Maywood ES \& Hastings MH 2019 Cell-autonomous clock of astrocytes drives circadian behavior in mammals. Science 363 187192. (https://doi.org/10.1126/science.aat4104)

Brancaccio M, Patton AP, Chesham JE, Maywood ES \& Hastings MH 2017 Astrocytes control circadian timekeeping in the suprachiasmatic nucleus via glutamatergic signaling. Neuron 93 1420-1435.e5. (https://doi.org/10.1016/j.neuron.2017.02.030)

Buhr ED, Yoo SH \& Takahashi JS 2010 Temperature as a universal resetting cue for mammalian circadian oscillators. Science 330379 385. (https://doi.org/10.1126/science.1195262)

Chaix A, Lin T, Le HD, Chang MW \& Panda S 2019 Time-restricted feeding prevents obesity and metabolic syndrome in mice lacking a circadian clock. Cell Metabolism 29 303-319.e4. (https://doi. org/10.1016/j.cmet.2018.08.004)

Challet E 2019 The circadian regulation of food intake. Nature Reviews. Endocrinology 15 393-405. (https://doi.org/10.1038/s41574-0190210-x)

Cho H, Zhao X, Hatori M, Yu RT, Barish GD, Lam MT, Chong LW, Ditacchio L, Atkins AR, Glass CK, et al. 2012 Regulation of circadian behaviour and metabolism by REV-ERB-alpha and REV-ERB-beta. Nature 485 123-127. (https://doi.org/10.1038/nature11048) 
Crosby P, Hamnett R, Putker M, Hoyle NP, Reed M, Karam CJ, Maywood ES, Stangherlin A, Chesham JE, Hayter EA, et al. 2019 Insulin/IGF-1 drives PERIOD synthesis to entrain circadian rhythms with feeding time. Cell 177 896-909.e20. (https://doi.org/10.1016/j. cell.2019.02.017)

Damiola F, Le Minh N, Preitner N, Kornmann B, Fleury-Olela F \& Schibler U 2000 Restricted feeding uncouples circadian oscillators in peripheral tissues from the central pacemaker in the suprachiasmatic nucleus. Genes \& Development 14 2950-2961. (https://doi. org/10.1101/gad.183500)

Delezie J, Dumont S, Dardente H, Oudart H, Grechez-Cassiau A, Klosen P, Teboul M, Delaunay F, Pevet P \& Challet E 2012 The nuclear receptor REV-ERBalpha is required for the daily balance of carbohydrate and lipid metabolism. FASEB Journal 26 3321-3335. (https://doi.org/10.1096/fj.12-208751)

Di Francesco A, Di Germanio C, Bernier M \& De Cabo R 2018 A time to fast. Science 362 770-775. (https://doi.org/10.1126/science.aau2095)

Dunlap JC 1999 Molecular bases for circadian clocks. Cell 96 271-290. (https://doi.org/10.1016/s0092-8674(00)80566-8)

Dyar KA, Ciciliot S, Wright LE, Bienso RS, Tagliazucchi GM, Patel VR, Forcato M, Paz MI, Gudiksen A, Solagna F, et al. 2014 Muscle insulin sensitivity and glucose metabolism are controlled by the intrinsic muscle clock. Molecular Metabolism 3 29-41. (https://doi. org/10.1016/j.molmet.2013.10.005)

Dyar KA, Lutter D, Artati A, Ceglia NJ, Liu Y, Armenta D, Jastroch M, Schneider S, De Mateo S, Cervantes M, et al. 2018 Atlas of circadian metabolism reveals system-wide coordination and communication between clocks. Cell 174 1571-1585.e11. (https://doi.org/10.1016/j. cell.2018.08.042)

Eckel-Mahan KL, Patel VR, De Mateo S, Orozco-Solis R, Ceglia NJ, Sahar S, Dilag-Penilla SA, Dyar KA, Baldi P \& Sassone-Corsi P 2013 Reprogramming of the circadian clock by nutritional challenge. Cell 155 1464-1478. (https://doi.org/10.1016/j.cell.2013.11.034)

Furlan A, Jacquier M, Woller A, Heliot L, Duez H, Staels B \& Lefranc M 2019 Mathematical models converge on PGC1alpha as the key metabolic integrator of SIRT1 and AMPK regulation of the circadian clock. Proceedings of the National Academy of Sciences of the United States of America 116 13171-13172. (https://doi.org/10.1073/ pnas.1907751116)

Gallego M \& Virshup DM 2007 Post-translational modifications regulate the ticking of the circadian clock. Nature Reviews. Molecular Cell Biology 8 139-148. (https://doi.org/10.1038/nrm2106)

Gekakis N, Staknis D, Nguyen HB, Davis FC, Wilsbacher LD, King DP, Takahashi JS \& Weitz CJ 1998 Role of the CLOCK protein in the mammalian circadian mechanism. Science 280 1564-1569. (https:// doi.org/10.1126/science.280.5369.1564)

Golombek DA \& Rosenstein RE 2010 Physiology of circadian entrainment. Physiological Reviews 90 1063-1102. (https://doi. org/10.1152/physrev.00009.2009)

Green CB, Takahashi JS \& Bass J 2008 The meter of metabolism. Cell 134 728-742. (https://doi.org/10.1016/j.cell.2008.08.022)

Greenham K \& McClung CR 2015 Integrating circadian dynamics with physiological processes in plants. Nature Reviews. Genetics 16 598610. (https://doi.org/10.1038/nrg3976)

Greenwell BJ, Trott AJ, Beytebiere JR, Pao S, Bosley A, Beach E, Finegan P, Hernandez C \& Menet JS 2019 Rhythmic food intake drives rhythmic gene expression more potently than the hepatic circadian clock in mice. Cell Reports 27 649-657.e5. (https://doi. $\operatorname{org} / 10.1016 /$ j.celrep.2019.03.064)

Guler AD, Ecker JL, Lall GS, Haq S, Altimus CM, Liao HW, Barnard AR, Cahill H, Badea TC, Zhao H, et al. 2008 Melanopsin cells are the principal conduits for rod-cone input to non-image-forming vision. Nature 453 102-105. (https://doi.org/10.1038/nature06829)

Hardin PE, Hall JC \& Rosbash M 1990 Feedback of the Drosophila period gene product on circadian cycling of its messenger RNA levels. Nature 343 536-540. (https://doi.org/10.1038/343536a0)
Harfmann BD, Schroder EA, Kachman MT, Hodge BA, Zhang X \& Esser KA 2016 Muscle-specific loss of Bmal1 leads to disrupted tissue glucose metabolism and systemic glucose homeostasis. Skeletal Muscle 6 12. (https://doi.org/10.1186/s13395-016-0082-x)

Hastings MH, Maywood ES \& Brancaccio M 2018 Generation of circadian rhythms in the suprachiasmatic nucleus. Nature Reviews. Neuroscience 19 453-469. (https://doi.org/10.1038/s41583-0180026-z)

Hatori M, Vollmers C, Zarrinpar A, Ditacchio L, Bushong EA, Gill S, Leblanc M, Chaix A, Joens M, Fitzpatrick JA, et al. 2012 Timerestricted feeding without reducing caloric intake prevents metabolic diseases in mice fed a high-fat diet. Cell Metabolism 15 848-860. (https://doi.org/10.1016/j.cmet.2012.04.019)

Hattar S, Liao HW, Takao M, Berson DM \& Yau KW 2002 Melanopsincontaining retinal ganglion cells: architecture, projections, and intrinsic photosensitivity. Science 295 1065-1070. (https://doi. org/10.1126/science.1069609)

Hirano A, Yumimoto K, Tsunematsu R, Matsumoto M, Oyama M, Kozuka-Hata H, Nakagawa T, Lanjakornsiripan D, Nakayama KI \& Fukada Y 2013 FBXL21 regulates oscillation of the circadian clock through ubiquitination and stabilization of cryptochromes. Cell $\mathbf{1 5 2}$ 1106-1118. (https://doi.org/10.1016/j.cell.2013.01.054)

Ikeda Y, Kamagata M, Hirao M, Yasuda S, Iwami S, Sasaki H, Tsubosaka M, Hattori Y, Todoh A, Tamura K, et al. 2018 Glucagon and/or IGF-1 production regulates resetting of the liver circadian clock in response to a protein or amino acid-only diet. EBiomedicine 28 210-224. (https://doi.org/10.1016/j.ebiom.2018.01.012)

Izumo M, Pejchal M, Schook AC, Lange RP, Walisser JA, Sato TR, Wang X, Bradfield CA \& Takahashi JS 2014 Differential effects of light and feeding on circadian organization of peripheral clocks in a forebrain Bmal1 mutant. ELife 3. (https://doi.org/10.7554/ eLife.04617)

Kanehisa M, Furumichi M, Tanabe M, Sato Y \& Morishima K 2017 KEGG: new perspectives on genomes, pathways, diseases and drugs. Nucleic Acids Research 45 D353-D361. (https://doi.org/10.1093/nar/ gkw1092)

Kanehisa M \& Goto S 2000 KEGG: Kyoto encyclopedia of genes and genomes. Nucleic Acids Research 28 27-30. (https://doi.org/10.1093/ nar/28.1.27)

Katada S \& Sassone-Corsi P 2010 The histone methyltransferase MLL1 permits the oscillation of circadian gene expression. Nature Structural \& Molecular Biology 17 1414-1421. (https://doi.org/10.1038/ nsmb.1961)

Kim YH, Marhon SA, Zhang Y, Steger DJ, Won KJ \& Lazar MA 2018 Reverb $\alpha$ dynamically modulates chromatin looping to control circadian gene transcription. Science 359 1274-1277. (https://doi.org/10.1126/ science.aao6891)

King DP, Zhao Y, Sangoram AM, Wilsbacher LD, Tanaka M, Antoch MP, Steeves TD, Vitaterna MH, Kornhauser JM, Lowrey PL, et al. 1997 Positional cloning of the mouse circadian clock gene. Cell $89641-$ 653. (https://doi.org/10.1016/s0092-8674(00)80245-7)

Koike N, Yoo SH, Huang HC, Kumar V, Lee C, Kim TK \& Takahashi JS 2012 Transcriptional architecture and chromatin landscape of the core circadian clock in mammals. Science 338 349-354. (https://doi. org/10.1126/science.1226339)

Kojima S \& Green CB 2015 Circadian genomics reveal a role for posttranscriptional regulation in mammals. Biochemistry 54 124-133. (https://doi.org/10.1021/bi500707c)

Kojima S, Shingle DL \& Green CB 2011 Post-transcriptional control of circadian rhythms. Journal of Cell Science 124 311-320. (https://doi. org/10.1242/jcs.065771)

Konopka RJ \& Benzer S 1971 Clock mutants of Drosophila melanogaster. Proceedings of the National Academy of Sciences of the United States of America 68 2112-2116. (https://doi.org/10.1073/pnas.68.9.2112)

Koronowski KB, Kinouchi K, Welz PS, Smith JG, Zinna VM, Shi J, Samad M, Chen S, Magnan CN, Kinchen JM, et al. 2019 Defining 
the independence of the liver circadian clock. Cell 177 1448-1462. e14. (https://doi.org/10.1016/i.cell.2019.04.025)

Kume K, Zylka MJ, Sriram S, Shearman LP, Weaver DR, Jin X, Maywood ES, Hastings MH \& Reppert SM 1999 mCRY1 and mCRY2 are essential components of the negative limb of the circadian clock feedback loop. Cell 98 193-205. (https://doi.org/10.1016/s00928674(00)81014-4)

Lamia KA, Papp SJ, Yu RT, Barish GD, Uhlenhaut NH, Jonker JW, Downes M \& Evans RM 2011 Cryptochromes mediate rhythmic repression of the glucocorticoid receptor. Nature $\mathbf{4 8 0} 552-556$. (https://doi.org/10.1038/nature10700)

Lamia KA, Sachdeva UM, Ditacchio L, Williams EC, Alvarez JG, Egan DF, Vasquez DS, Juguilon H, Panda S, Shaw RJ, et al. 2009 AMPK regulates the circadian clock by cryptochrome phosphorylation and degradation. Science 326 437-440. (https://doi.org/10.1126/ science.1172156)

Le Martelot G, Canella D, Symul L, Migliavacca E, Gilardi F, Liechti R, Martin O, Harshman K, Delorenzi M, Desvergne B, et al. 2012 Genome-wide RNA polymerase II profiles and RNA accumulation reveal kinetics of transcription and associated epigenetic changes during diurnal cycles. PLOS Biology 10 e1001442. (https://doi. org/10.1371/journal.pbio.1001442)

Lee Y, Lee J, Kwon I, Nakajima Y, Ohmiya Y, Son GH, Lee KH \& Kim K 2010 Coactivation of the CLOCK-BMAL1 complex by CBP mediates resetting of the circadian clock. Journal of Cell Science 123 35473557. (https://doi.org/10.1242/jcs.070300)

Lightman S 2016 Rhythms within rhythms: the importance of oscillations for glucocorticoid hormones. In Eds. P Sassone-Corsi \& Y Christen A Time for Metabolism and Hormones. pp 87-99, Cham (CH): Springer.

Lim C \& Allada R 2013 Emerging roles for post-transcriptional regulation in circadian clocks. Nature Neuroscience 16 1544-1550. (https://doi.org/10.1038/nn.3543)

Marcheva B, Ramsey KM, Buhr ED, Kobayashi Y, Su H, Ko CH, Ivanova G, Omura C, Mo S, Vitaterna MH, et al. 2010 Disruption of the clock components CLOCK and BMAL1 leads to hypoinsulinaemia and diabetes. Nature 466 627-631. (https://doi. org/10.1038/nature09253)

Masri S, Patel VR, Eckel-Mahan KL, Peleg S, Forne I, Ladurner AG, Baldi P, Imhof A \& Sassone-Corsi P 2013 Circadian acetylome reveals regulation of mitochondrial metabolic pathways. Proceedings of the National Academy of Sciences of the United States of America 1103339 3344. (https://doi.org/10.1073/pnas.1217632110)

Menet JS, Pescatore S \& Rosbash M 2014 CLOCK:BMAL1 is a pioneerlike transcription factor. Genes \& Development 28 8-13. (https://doi. org/10.1101/gad.228536.113)

Menet JS, Rodriguez J, Abruzzi KC \& Rosbash M 2012 Nascent-Seq reveals novel features of mouse circadian transcriptional regulation. ELife 1 e00011. (https://doi.org/10.7554/eLife.00011)

Mermet J, Yeung J, Hurni C, Mauvoisin D, Gustafson K, Jouffe C, Nicolas D, Emmenegger Y, Gobet C, Franken P, et al. 2018 Clockdependent chromatin topology modulates circadian transcription and behavior. Genes \& Development 32 347-358. (https://doi. org/10.1101/gad.312397.118)

Michael AK, Fribourgh JL, Chelliah Y, Sandate CR, Hura GL, Schneidman-Duhovny D, Tripathi SM, Takahashi JS \& Partch CL 2017 Formation of a repressive complex in the mammalian circadian clock is mediated by the secondary pocket of CRY1. Proceedings of the National Academy of Sciences of the United States of America 114 15601565. (https://doi.org/10.1073/pnas.1615310114)

Mohawk JA, Green CB \& Takahashi JS 2012 Central and peripheral circadian clocks in mammals. Annual Review of Neuroscience 35445 462. (https://doi.org/10.1146/annurev-neuro-060909-153128)

Moore RY \& Eichler VB 1972 Loss of a circadian adrenal corticosterone rhythm following suprachiasmatic lesions in the rat. Brain Research 42 201-206. (https://doi.org/10.1016/0006-8993(72)90054-6)
Moore RY \& Lenn NJ 1972 A retinohypothalamic projection in the rat. Journal of Comparative Neurology 146 1-14. (https://doi.org/10.1002/ cne.901460102)

Mukherji A, Kobiita A, Damara M, Misra N, Meziane H, Champy MF \& Chambon P 2015 Shifting eating to the circadian rest phase misaligns the peripheral clocks with the master SCN clock and leads to a metabolic syndrome. Proceedings of the National Academy of Sciences of the United States of America 112 E6691-E6698. (https://doi. org/10.1073/pnas.1519807112)

Nakahata Y, Kaluzova M, Grimaldi B, Sahar S, Hirayama J, Chen D, Guarente LP \& Sassone-Corsi P 2008 The NAD+-dependent deacetylase SIRT1 modulates CLOCK-mediated chromatin remodeling and circadian control. Cell 134 329-340. (https://doi. org/10.1016/j.cell.2008.07.002)

Narasimamurthy R, Hunt SR, Lu Y, Fustin JM, Okamura H, Partch CL, Forger DB, Kim JK \& Virshup DM 2018 CK1delta/epsilon protein kinase primes the PER2 circadian phosphoswitch. Proceedings of the National Academy of Sciences of the United States of America 115 59865991. (https://doi.org/10.1073/pnas.1721076115)

Okamura H, Berod A, Julien JF, Geffard M, Kitahama K, Mallet J \& Bobillier P 1989 Demonstration of GABAergic cell bodies in the suprachiasmatic nucleus: in situ hybridization of glutamic acid decarboxylase (GAD) mRNA and immunocytochemistry of GAD and GABA. Neuroscience Letters 102 131-136. (https://doi. org/10.1016/0304-3940(89)90067-0)

Pacheco-Bernal I, Becerril-Perez F \& Aguilar-Arnal L 2019 Circadian rhythms in the three-dimensional genome: implications of chromatin interactions for cyclic transcription. Clinical Epigenetics $\mathbf{1 1}$ 79. (https://doi.org/10.1186/s13148-019-0677-2)

Panda S, Antoch MP, Miller BH, Su AI, Schook AB, Straume M, Schultz PG, Kay SA, Takahashi JS \& Hogenesch JB 2002 Coordinated transcription of key pathways in the mouse by the circadian clock. Cell 109 307-320. (https://doi.org/10.1016/s0092-8674(02)00722-5)

Perelis M, Marcheva B, Ramsey KM, Schipma MJ, Hutchison AL, Taguchi A, Peek CB, Hong H, Huang W, Omura C, et al. 2015 Pancreatic beta cell enhancers regulate rhythmic transcription of genes controlling insulin secretion. Science 350 aac4250. (https://doi. org/10.1126/science.aac4250)

Pittendrigh CS 1960 Circadian rhythms and the circadian organization of living systems. Cold Spring Harbor Symposia on Quantitative Biology 25 159-184. (https://doi.org/10.1101/sqb.1960.025.01.015)

Pittendrigh CS 1993 Temporal organization: reflections of a Darwinian clock-watcher. Annual Review of Physiology 55 16-54. (https://doi. org/10.1146/annurev.ph.55.030193.000313)

Pittendrigh CS \& Daan S 1976 A functional analysis of circadian pacemakers in nocturnal rodents. Journal of Comparative Physiology 106 223-252. (https://doi.org/10.1007/BF01417856)

Porterfield VM, Piontkivska H \& Mintz EM 2007 Identification of novel light-induced genes in the suprachiasmatic nucleus. $B M C$ Neuroscience 8 98. (https://doi.org/10.1186/1471-2202-8-98)

Preitner N, Damiola F, Lopez-Molina L, Zakany J, Duboule D, Albrecht U \& Schibler U 2002 The orphan nuclear receptor REV-ERBalpha controls circadian transcription within the positive limb of the mammalian circadian oscillator. Cell 110 251-260. (https://doi. org/10.1016/s0092-8674(02)00825-5)

Provencio I, Rodriguez IR, Jiang G, Hayes WP, Moreira EF \& Rollag MD 2000 A novel human opsin in the inner retina. Journal of Neuroscience 20 600-605. (https://doi.org/10.1523/ JNEUROSCI.20-02-00600.2000)

Ralph MR, Foster RG, Davis FC \& Menaker M 1990 Transplanted suprachiasmatic nucleus determines circadian period. Science $\mathbf{2 4 7}$ 975-978. (https://doi.org/10.1126/science.2305266)

Reddy P, Zehring WA, Wheeler DA, Pirrotta V, Hadfield C, Hall JC \& Rosbash M 1984 Molecular analysis of the period locus in Drosophila melanogaster and identification of a transcript involved 
in biological rhythms. Cell 38 701-710. (https://doi. org/10.1016/0092-8674(84)90265-4)

Reischl S, Vanselow K, Westermark PO, Thierfelder N, Maier B, Herzel H \& Kramer A 2007 Beta-TrCP1-mediated degradation of PERIOD2 is essential for circadian dynamics. Journal of Biological Rhythms 22 375-386. (https://doi.org/10.1177/0748730407303926)

Ripperger JA \& Schibler U 2006 Rhythmic CLOCK-BMAL1 binding to multiple E-box motifs drives circadian Dbp transcription and chromatin transitions. Nature Genetics 38 369-374. (https://doi. org/10.1038/ng1738)

Rosensweig C, Reynolds KA, Gao P, Laothamatas I, Shan Y, Ranganathan R, Takahashi JS \& Green CB 2018 An evolutionary hotspot defines functional differences between CRYPTOCHROMES. Nature Communications 9 1138. (https://doi.org/10.1038/s41467-018-03503-6)

Saini C, Liani A, Curie T, Gos P, Kreppel F, Emmenegger Y, Bonacina L, Wolf JP, Poget YA, Franken P, et al. 2013 Real-time recording of circadian liver gene expression in freely moving mice reveals the phase-setting behavior of hepatocyte clocks. Genes \& Development 27 1526-1536. (https://doi.org/10.1101/gad.221374.113)

Sato TK, Panda S, Miraglia LJ, Reyes TM, Rudic RD, Mcnamara P, Naik KA, Fitzgerald GA, Kay SA \& Hogenesch JB 2004 A functional genomics strategy reveals Rora as a component of the mammalian circadian clock. Neuron 43 527-537. (https://doi.org/10.1016/j. neuron.2004.07.018)

Schibler U, Gotic I, Saini C, Gos P, Curie T, Emmenegger Y, Sinturel F, Gosselin P, Gerber A, Fleury-Olela F, et al. 2015 Clock-talk: interactions between central and peripheral circadian oscillators in mammals. Cold Spring Harbor Symposia on Quantitative Biology 80 223-232. (https://doi.org/10.1101/sqb.2015.80.027490)

Shearman LP, Zylka MJ, Weaver DR, Kolakowski LF. \& Reppert SM 1997 Two period homologs: circadian expression and photic regulation in the suprachiasmatic nuclei. Neuron 19 1261-1269. (https://doi. org/10.1016/s0896-6273(00)80417-1)

Smith RF \& Konopka RJ 1981 Circadian clock phenotypes of chromosome aberrations with a breakpoint at the per locus. Molecular \& General Genetics 183 243-251. (https://doi.org/10.1007/ bf00270625)

Stephan FK \& Zucker I 1972 Circadian rhythms in drinking behavior and locomotor activity of rats are eliminated by hypothalamic lesions. Proceedings of the National Academy of Sciences of the United States of America 69 1583-1586. (https://doi.org/10.1073/ pnas.69.6.1583)

Stokkan KA, Yamazaki S, Tei H, Sakaki Y \& Menaker M 2001 Entrainment of the circadian clock in the liver by feeding. Science 291 490-493. (https://doi.org/10.1126/science.291.5503.490)

Storch KF, Lipan O, Leykin I, Viswanathan N, Davis FC, Wong WH \& Weitz CJ 2002 Extensive and divergent circadian gene expression in liver and heart. Nature $\mathbf{4 1 7}$ 78-83. (https://doi.org/10.1038/ nature744)

Stratmann M, Stadler F, Tamanini F, Van Der Horst GT \& Ripperger JA 2010 Flexible phase adjustment of circadian albumin D site-binding protein (DBP) gene expression by CRYPTOCHROME1. Genes \& Development 24 1317-1328. (https://doi.org/10.1101/gad.578810)

Sun Z, Feng D, Everett LJ, Bugge A \& Lazar MA 2011 Circadian epigenomic remodeling and hepatic lipogenesis: lessons from HDAC3. Cold Spring Harbor Symposia on Quantitative Biology 76 4955. (https://doi.org/10.1101/sqb.2011.76.011494)

Takahashi JS 2017 Transcriptional architecture of the mammalian circadian clock. Nature Reviews. Genetics 18 164-179. (https://doi. org/10.1038/nrg.2016.150)

Turek FW, Joshu C, Kohsaka A, Lin E, Ivanova G, Mcdearmon E, Laposky A, Losee-Olson S, Easton A, Jensen DR, et al. 2005 Obesity and metabolic syndrome in circadian clock mutant mice. Science $\mathbf{3 0 8}$ 1043-1045. (https://doi.org/10.1126/science.1108750)

Ueda HR, Chen W, Adachi A, Wakamatsu H, Hayashi S, Takasugi T, Nagano M, Nakahama K, Suzuki Y, Sugano S, et al. 2002 A transcription factor response element for gene expression during circadian night. Nature 418 534-539. (https://doi.org/10.1038/ nature00906)

Ueda HR, Hayashi S, Chen W, Sano M, Machida M, Shigeyoshi Y, Iino M \& Hashimoto S 2005 System-level identification of transcriptional circuits underlying mammalian circadian clocks. Nature Genetics $\mathbf{3 7}$ 187-192. (https://doi.org/10.1038/ng1504)

Vitaterna MH, King DP, Chang AM, Kornhauser JM, Lowrey PL, Mcdonald JD, Dove WF, Pinto LH, Turek FW \& Takahashi JS 1994 Mutagenesis and mapping of a mouse gene, Clock, essential for circadian behavior. Science 264 719-725. (https://doi.org/10.1126/ science.8171325)

Vollmers C, Gill S, Ditacchio L, Pulivarthy SR, Le HD \& Panda S 2009 Time of feeding and the intrinsic circadian clock drive rhythms in hepatic gene expression. Proceedings of the National Academy of Sciences of the United States of America 106 21453-21458. (https://doi. org/10.1073/pnas.0909591106)

Vollmers C, Schmitz RJ, Nathanson J, Yeo G, Ecker JR \& Panda S 2012 Circadian oscillations of protein-coding and regulatory RNAs in a highly dynamic mammalian liver epigenome. Cell Metabolism 16 833-845. (https://doi.org/10.1016/j.cmet.2012.11.004)

Wang J, Symul L, Yeung J, Gobet C, Sobel J, Luck S, Westermark PO, Molina N \& Naef F 2018 Circadian clock-dependent and -independent posttranscriptional regulation underlies temporal mRNA accumulation in mouse liver. Proceedings of the National Academy of Sciences of the United States of America 115 E1916-E1925. (https://doi.org/10.1073/pnas.1715225115)

Weindruch R, Walford RL, Fligiel S \& Guthrie D 1986 The retardation of aging in mice by dietary restriction: longevity, cancer, immunity and lifetime energy intake. Journal of Nutrition 116 641-654. (https://doi. org/10.1093/jn/116.4.641)

Welsh DK, Takahashi JS \& Kay SA 2010 Suprachiasmatic nucleus: cell autonomy and network properties. Annual Review of Physiology $\mathbf{7 2}$ 551-577. (https://doi.org/10.1146/annurev-physiol-021909-135919)

Welsh DK, Yoo SH, Liu AC, Takahashi JS \& Kay SA 2004 Bioluminescence imaging of individual fibroblasts reveals persistent, independently phased circadian rhythms of clock gene expression. Current Biology 14 2289-2295. (https://doi.org/10.1016/j. cub.2004.11.057)

Xu Y, Guo W, Li P, Zhang Y, Zhao M, Fan Z, Zhao Z \& Yan J 2016 Longrange chromosome interactions mediated by cohesin shape circadian gene expression. PLOS Genetics 12 e1005992. (https://doi. org/10.1371/journal.pgen.1005992)

Yagita K, Tamanini F, Van Der Horst GT \& Okamura H 2001 Molecular mechanisms of the biological clock in cultured fibroblasts. Science 292 278-281. (https://doi.org/10.1126/science.1059542)

Yamazaki S, Numano R, Abe M, Hida A, Takahashi R, Ueda M, Block GD, Sakaki Y, Menaker M \& Tei H 2000 Resetting central and peripheral circadian oscillators in transgenic rats. Science $\mathbf{2 8 8} 682$ 685. (https://doi.org/10.1126/science.288.5466.682)

Yeung J, Mermet J, Jouffe C, Marquis J, Charpagne A, Gachon F \& Naef F 2018 Transcription factor activity rhythms and tissue-specific chromatin interactions explain circadian gene expression across organs. Genome Research 28 182-191. (https://doi.org/10.1101/ gr.222430.117)

Yeung J \& Naef F 2018 Rhythms of the genome: circadian dynamics from chromatin topology, tissue-specific gene expression, to behavior. Trends in Genetics 34 915-926. (https://doi.org/10.1016/j. tig.2018.09.005)

Yoo SH, Mohawk JA, Siepka SM, Shan Y, Huh SK, Hong HK, Kornblum I, Kumar V, Koike N, Xu M, et al. 2013 Competing E3 ubiquitin ligases govern circadian periodicity by degradation of CRY in nucleus and cytoplasm. Cell 152 1091-1105. (https://doi.org/10.1016/j. cell.2013.01.055)

Yoo SH, Yamazaki S, Lowrey PL, Shimomura K, Ko CH, Buhr ED, Siepka SM, Hong HK, Oh WJ, Yoo OJ, et al. 2004 
PERIOD2::luciferase real-time reporting of circadian dynamics reveals persistent circadian oscillations in mouse peripheral tissues. Proceedings of the National Academy of Sciences of the United States of America 101 5339-5346. (https://doi.org/10.1073/ pnas.0308709101)

Zhang EE, Liu Y, Dentin R, Pongsawakul PY, Liu AC, Hirota T, Nusinow DA, Sun X, Landais S, Kodama Y, et al. 2010 Cryptochrome mediates circadian regulation of cAMP signaling and hepatic gluconeogenesis. Nature Medicine 16 1152-1156. (https://doi. org/10.1038/nm.2214)
Zhang R, Lahens NF, Ballance HI, Hughes ME \& Hogenesch JB 2014 A circadian gene expression atlas in mammals: implications for biology and medicine. Proceedings of the National Academy of Sciences of the United States of America 111 16219-16224. (https://doi.org/10.1073/ pnas.1408886111)

Zhang Y, Fang B, Emmett MJ, Damle M, Sun Z, Feng D, Armour SM, Remsberg JR, Jager J, Soccio RE, et al. 2015 GENE REGULATION. Discrete functions of nuclear receptor Rev-erbalpha couple metabolism to the clock. Science 348 1488-1492. (https://doi. org/10.1126/science.aab3021)

Received in final form 17 September 2019

Accepted 26 September 2019

Accepted Preprint published online 26 September 2019
(C) 2019 Society for Endocrinology Published by Bioscientifica Ltd. Printed in Great Britain 